as. Edward Lipinski, Louvain

\title{
PIERWSZY MIĘDZYNARODOWY KATOLICKI KONGRES NAUK BIBLIJNYCH
}

Od dziesięciu lat Katolicki Uniwersytet w Louvain organizuje co roku „Tydzień Studiów Biblijnych" w którym za każdym razem bierze udział około stu profesorów Pisma Swiętego ${ }^{1}$ ). Głównym promotorem tych tak owocnych dla biblistyki spotkań jest Ks. Prałat J. Coppens, profesor egzegezy Starego Testamentu i obecny dziekan wydziału teologii.

Z okazji Brukselskiej Wystawy Swiatowej komitet organizacyjny „Tygodni Studiów Biblijnych" Uniwersytetu w Louvain postanowił zwołać na rok 1958 Międzynarodowy Katolicki Kongres Nauk Biblijnych. $\mathrm{Na}$ apel odpowiedziało około 450 biblistów. Wśród nich znaleźli się nieomal wszyscy wybitniejsi egzegeci katoliccy dzisiejszej doby. Na czele komitetu organizacyjnego stanął Ks. Prałat J. C op pen s; zastępca jego był O. F. M. Bra un, OP.; urząd sekretarza kongresu piastował. Ks. Kan. Ed. Massaux.

Kongres obradował w Brukseli i w Louvain od 25-30. VIII. i przy udziale egzegetów katolickich z 24 krajów. Nic też dziwnego, że hierarchia kościelna okazała tyle sympatii temu Kongresowi Nauk Biblijnych.

W pierwszym rzędzie należy tu wymienić własnoręczny list Ojca Swiętego. W liście tym Papież Pius XII pisał między innymi: „Od poczatku Naszego Pontyfikatu staraliśmy się poprzeć rozwój nauk biblijnych i przed piętnastu blisko laty chcieliśmy przez $\mathrm{Na}$ sza encyklike „Divino afflante Spiritu“ jeszcze bardziej zachęcić

1) Dotychczas ukazały się w druku referaty wygłoszone na zjazdach lat 1953 (.L'Attente du Messie" w serii "Recherches B i b li ques" I, Bruges 1954), (,L'Ancen Testament et l'Orient" $w$ serii .Orientalia e $\dot{\tau}$ Riblica Lovaniensi a" I, Louvain 1957), 1955 (.,La Formation des Evangles" w serii "R e cherches Bibliques" II. Bruges 1957) i 1956 ("L'Evangile de Jean" w serii ,R e cherches Bibliques" III, Bruges 1958). Są już przygotowane do druku uzupełnione referaty zjazdu roku 1957, które ukażą się pod tytułem „La Secte de Qurnran et les Origines du Christianisme" w serii "Recherches Bibliques". 
do ich pracy tych wszystkich synów Kościoła, którzy oddaja się tym studiom, oraz nakłonić ich do dalszego prowadzenia z pełnym zapałem, $z$ największa starannościa $i$ z energia zawsze świeża: dzieła szczęśliwie rozpoczetego. Następnie - o czym dobrze wiecie - nigdy nie zaprzestaliśmy okazywać Nasza troskliwość biblistom $i$ profesprom Pisma Świętego. Tote $\dot{z} z$ radościa przesyłamy Nasze Ojcowskie życzenia profesorom katolickim, którzy zbieraja sie $w$ Brukseli, aby podzielić sie zasobem swej wiedzy i przyczynić się do postępu wszystkich gałęzi nauki, które niezbędne sa dla lepszego zrozumienia ksiag natchnionych. Oby z ufnościa prowadzili dalej swe badania, posłuszni Kościołowi, Stróżowi i Tłumaczowi Pisma Świętego, oraz silni poważaniem, jakie żywimy dla ich żmudnej czasami ale tak ważnej pracy. W ten sposób bowiem: wielce przyczyniaja się do zbawienia dusz, do postępu sprawy katolickiej, do oddania Bogu czci i chwaly oraz wykonuja prace ściśle zwiazana z obowiazkiem krzewienia wiary".

Prócz tego listu, w odpowiedzi na wyrazy synowskiego oddania przesłane $\mathrm{Mu}$ przez uczestników kongresu, Ojciec św. nadesłał jeszcze telegram, w którym wyraził życzenie, aby kongresiści ,wynieśli $z$ tych obrad serca gorejace czystszym jeszcze i silniejszym zapaŁem do czczenia $i$ badania Pisma Świętego; świecac przykzadem swej wierności nauczycielskiemu urzędowi Kościoła". Zachęca również wszystkich, którzy wzięli udział w tym kongresie, ,aby gorliwie szukali serca Boga $w$ słowie Bożym i $w$ ten sposób $w$ cnocie postępowali". Słowa te miały być jakby ostatnim zleceniem danym biblistom katolickim przez wielkiego Papieża, który dzięki swej encyklice „Divino afflante Spiritu“ zapoczątkował nową ere w biblistyce katolickiej.

Trosce hierarchii kościelnej o rozwój nauk biblijnych dała jeszcze wyraz obecność na uroczystym otwarciu kongresu dwóch kardynałów: J. Em. Ks. Kardynała J. E. V a n R o e y, Prymasa Belgii, oraz J. Em. Ks. Kardynała R u f i n i, arcybiskupa Palermo. jak również szeregu biskupów belgijskich, holenderskich i luksemburskich.

Co więcej, na sesji inauguracyjnej, która odbyła się na terenie wystawowym $\mathrm{w}$ wielkim audytorium pawilonu Stolicy Apostolskiej, J. E. Ks. Biskup A-M. Charue, ordynariusz diecezji Namur i były profesor biblistyki, wygłosił referat wstępny na temat roli i zadania biblistów w życiu Kościoła. Zdaniem Ks. Biskupa Charue głównym celem egzegetów katolickich winno być podanie i wytłumaczenie wiernym tekstu Pisma Świętego, w czym oczywiście działaliby oni w ścisłej łączności z hierarchia kościelna i pod jej odpowiedzialnym nadzorem. 
Inny zaś przedstawiciel hierarchii Kościoła, J. E. Ks. Arcybiskup B. A Ifrink z Utrechtu, wygłosił ostatni referat Kongresu przypominajac biblistom wszystko, eo Stolica Apostolska uczy+ niła w ciągu tych ostatnich dziesięciu lat, aby skutecznie poprzeć rozwój nauk biblijnych. Ks. Arcybiskup B. Alfrink zwrócił szczególną uwagę na rolę i znaczenie dekretów Papieskiej Komisji Biblijnej, przestrzegając biblistów przed nieroztropnym rozpowszechnianiem nieugruntowanych jeszcze wyników badań naukowych. Ta łączność między hierarchią Kościoła a profesorami Uniwersytetów i Seminariów katolickich stanowiła jedną z wielu dodatnich cech tego Kongresu Nauk Biblijnych. Inną jego zaletą był wysoki poziom naukowy wygłoszonych odczyiów i przeprowadzonych dyskusji oraz idące $\mathrm{z}$ nim $\mathrm{w}$ parze szerokie zrozumienie cudzych opinii i poglądów.

Oprócz sesji plenarnych, które odbywały się przed południem, miały miejsce po południu zebrania sekcyjne. Sekcji było sześć:

Sekcja I — „W stęp ogólny do Pisma Świętego" prowadzila swe obrady pod przewodnictwem O. J. Levie, T. J., profesora Kolegium Teologicznego Tow. Jez.

Sekcji II, t. j. „Bliski e g o W s chod u“, przewodniczył Ks. Prałat G. Rijckmans, profesor Uniwersytetu w Louvain.

Sekcja III - „S rodowisko Nowego Testamentu“ — miała za przewodniczącego O. B. Riga ux O. F. M., profesora Kolegium Teologicznego O. Franciszkanów w Brukseli.

Sekcji IV, t. j. „Starego Testamentu“, prezydowal Ks. Prałat J. Coppens, profesor Uniwersytetu w Louvain.

Sekcji V, t. j. „Nowego Testamentu“, przewodniczy Ks. Prałat L. Cerfa $\mathrm{x}$, profesor Uniwersytetu w Louvain.

Sekcji VI, czyli „Teologii Biblijnej", prezydował Ks. Kan. P. van I m s h o ot, profesor honorowy Seminarium w Gandawie.

$\mathrm{Na}$ sesjach plenarnych i na zebraniach poszczególnych sekcji wygłoszono w sumie 75 referatów fachowych, które zostaną ogłoszone drukiem jako Akta Kongresu.

W nieobecności O. R. de V Vux O. P., rektora francuskiej Szkoły biblijnej i archeologicznej w Jerozolimie, pierwszy fachowy odczyt wygłosił O. P. Benoît O. P., profesor tejże szkoły. Tytuł referatu brzmiał: „Analogie natchnienia biblijnego". Zdaniem O. B en ồt nie można oddzielać myśli od słowa i pisma. Myśli zaś odzwierciedlają życie, które już jest dziełem Bożym. Natchnienie biblijne nie utożsamia się więc $\mathrm{z}$ natchnieniem ,piśmienniczym", t. j. z wpływem wywieranym przez Boga na umysł i wolę pisarza od chwili pobudzenia go do pisania aż do calkowitego ukończenia dzieła. Bóg bowiem kieruje wszystkimi wyda- 
rzeniami; stąd w samych rzeczach i faktach opisanych przez pisarzy natchnionych istniało już pewne natchnienie ,dramatyczne“", które udzieliło się myśli autorów biblijnych nim jeszcze Bóg nakłonił ich do przekazania ich na piśmie. Prócz tego Bóg obdarzył niektórych hagiografów natchnieniem „proroczym" względnie „apostolskim“, zanim jeszcze pobudził ich natchnieniem ,piśmienniczym" do spisania tych myśli inspirowanych im przez Boga. Biorąc pod uwagę tę różnorodność natchnienia biblijnego $\mathrm{O}$. B e n o ît sądzi, iż można stąd wywnioskować, że autorem natchnionym jest nie tylko pisarz nadający dziełu ostateczną jego szatee, że sens rzeczowy czyli typiczny jest rzeczywiście sensem biblijnym i natchnionym, że możliwy jest podwójny - choć nie sprzeczny w swej treści - wyrazowy sens biblijny, mianowicie sens zamierzony i wyrażony przez pisarza natchnionego oraz sens pierwotny tych zdań w umyśle proroka czy apostoła, którego słowa są przytoczone. Na koniec $\mathrm{O}$. B en oît podzielił się kilkoma refleksjami na temat analogii zachodzącej między natchnieniem biblijnym a działaniem Ducha Świętego w Kościele.

Po południu kongresiści przenieśli się z Brukseli do Louvain. sdzie miały się odbyć następne posiedzenia Kongresu.

W sekcji I, tj. „Wstępu ogólnego do Pisma Święte go", pierwsza godzina została poświęcona dyskusji nad przedpołudniowym referatem $\mathrm{O}$. B e noît. Dało się $w$ niej zauważyć ogólne dążenie do dosięgnięcia poprzez literę Pisma samego dzieła Bożego krystalizującego się w historycznym rozwoju Objawienia. Nastepnie zabrał głos Ks. Prałat P. P. S a y don, profesor Uniwersytetu Maltańskiego, który poruszył dwa zagađnienia z zakresu krytyki literackiej Starego Testamentu, mianowicie: pojęcie autorstwa u starożytnych Izraelitów oraz materialne komponowanie książki w epoce Starego Przymierza. Po czym O. J. L evi e T.J. z Louvain starał się nakreślić praktyczną metodę uzgodnienia interpretacji Pisma Świętego w egzegezie, apologetyce i teologii w myśl wytycznych podanych w encyklice ,Divino Afflante Spiritu“. Na koniec Ks. J. B. B a u e r, docent Uniwersytetu w Grazu (Austria) i redaktor mającego się wkrótce ukazać nowego słownika biblijnego, mówił o egzegezie Ojców Kościoła jako twórczyni symbolów.

W sekcji „Bliskiego Wschodu“ Dr G. Goossens, konserwator królewskiego Muzeum Historii i Sztuki w Brukseli, wygłosił odczyt na temat religijnej interpretacji historii wśród ludów starożytnego wschodu. W następnym referacie $\mathrm{Dr}$ B. van de W a 11 e, profesor Uniwersytetu w Liège (Belgia), poruszył zagadnienie ,boga pierwotnego" w religii staroegipskiej, tj. boga, który w tekstach religijnych i mitologicznych starożytnego Egiptu jest 
przedstawiony jako przyczyna wszelkiego bytu. Trzecim z kolei był referat Ks. R. Largement, profesora Instytutu Katolickiego w Paryżu. Na przykładzie pojęcia „Dnia Jahwy" i analogicznych pojęć liturgii sumeryjsko-akkadyjskiej Ks. Lar gement. starał się wykazać, iż pierwszy etap wszelkiej obiektywnej egzegezy biblijnej Starego Testamentu polega na zestawieniu danych biblijnych z obfitym materiałem wykopaliskowym, w postaci zwłaszcza dokumentów ze środowisk kulturalnych ościennych ludów starożytnego Wschodu, które tworzą jakoby historyczny i życiowy kontekst Biblii. Wreszcie O. J. P. de M en a s c e O. P. z Paryża poruszył problem wpływów religii irańskich na Stary Testament.

W sekcji „Środowiska Nowego Testamentu“ z pierwszym odczytem wystapił Ks. Prałat L. Ce rfa ux, słynny profesor Uniwersytetu w Louvain. Mówił on o wplywie misteriów hellenistycznych na język listów św. Pawła do Kolosan i Efezjan. Następnie O. P. R. M u r phy O. Carm., profesor Katolickiego Uniwersytetu w Waszyngtonie, przeprowadził porównaw:czą analize pojęcia „ciała" w manuskryptach qumrańskich i w liście św. Pawła do Rzymian, rozdz. 7-8. Na koniec O. B. C a ppelle OSB, opat klasztoru Mont-César i profesor Uniwersytetu w Louvain, poruszył problem biblijnych źródeł angelologii liturgicznej zawartej w prefacji Mszy św.

W sekcji „Starego Testamentu" pierwszym prelegentem miał być Ks. Dr St. $€$ a c h, profesor Katolickiego Uniwersytetu Lubelskiego. Ponieważ Ks. Prof. 1 a $\mathrm{ch}$ nie przybył nạ Kongres, pierwszy odczyt wygłosił O. L. Arnaldich P e r ot OFM, profesor Papieskiego Uniwersytetu w Salamance (Hiszpania). Wykazał on, że ani Pismo Święte, ani tradycja Ojców, ani dokumenty nauczycielskiego urzędu Kościoła nie wymagają, byśmy wierzyli w pochodzenie Ewy z ciała Adama. Następnie Ks. Ch. $\mathrm{H}$ a u ret, profesor Uniwersytetu w Strassburgu, podał nowa interpretację Gen 4, 17-24. Po czym O. B. M. W a m b a c q O. Praem. z Rzymu przeprowadził mistrzowska analizę Bar 1, 1-3, 8 wykazując brak jedności literackiej tej pierwszej księgi Barucha.

W sekcji „Nowego Testamentu“ O. J.'Dupont OSB z opactwa Saint-André (Belgia) podał egzegezę Mt 5, 48 (,Bądźcie tedy doskonałymi, jak doskonałym jest wasz Ojciec niebieski“) i Łk 6, 36 („Bądźcie miłosierni, tak jak Ojciec wasz jest miłosierny"). Po czym O. A. G e orge, profesor wydziału teologicznego $\mathrm{W}$ Lyonie, przeprowadził krytykę literacką i egzegeze przypowieści o siewcy ( $\mathrm{Mk} 4,1-9$ ). Następnie Ks. Kan. S. Munoz I g l e s i as z Madrytu poruszył w sposób bardzo oryginalny i głęboko naukowy problem ewangelii lat dziecięcych u Mateusza i Łukasza. Na koniec O. F. Gils CSS przeprowadził krytykę 
teorii E. Sjöberga (E. Sjöberg, „Der verborgene Menschensohn in den Evangelien", Lund 1955) o sekrecie mesjańskim $\mathrm{w}$ ewangeliach.

W sekcji VI Ks. M. Pein a d or Navarro z Madrytu wyjaśnił najpierw, na czym polega teologia biblijna i jaki winien być do niej stosunek egzegety i teologa. Następnie O. A-M. B runet O. P., profesor Uniwersytetu w Montrealu (Kanada), wyglosił odczyt na temat teologii, autora ksiagg Kronik, Ezdrasza i Nehemiasza. Zdaniem prelegenta kronikarz usiłuje podkreślić zasadnicze miejsce rodu Dawida w teokracji narodu izraelskiego. Stąd należy uważać jego dzieło jako wyraz mesjanizmu dawidowego. W trze$\operatorname{cim}$ z kolei referacie Ks. H. Gross z Trewiru wyjaśnił, w jaki sposób przestawianie tematów biblijnych ze sfery ziemskiej do transcendentnego świata rzeczy Bożych było ważnym elementem ciągłości a zarazem i historycznego rozwoju Objawienia Bożego w Starym Testamencie. Wreszcie O. J. D e Frain e T. J. z Louvain starał się wykazać, że królom izraelskim czy judzkim nie przysługiwała godność kapłańska.

Następnego dnia, t. j. we wtorek 26 sierpnia, plenarne posiedzenie Kongresu odbyło się w Wielkiej Auli Uniwersyteckiej w Louvain. Obradom przewodniczył Ks. J. Coppens. Wygłoszono dwa referaty. Najpierw Ks. A. Gelin z Lyonu poruszył problem pogłębiania pierwotnych tematów biblijnych przez późniejszych ich czytelników pojmujących i interpretujących je $\mathrm{w}$ świetle żywej tradycji historycznego rozwoju Objawienia Bożego. Zdaniem prelegenta te późniejsze i pogłębiające treść tekstu rozważania niekiedy pozostawiły po sobie ślad w samym tekście natchnionym $w$ postaci glos, zmian lub uzupełnień wprowadzonych do tekstu $\mathrm{w}$ przeciagu wieków. Zmiany te zostałyby przeprowadzone pod kontrolą i odpowiedzialnością religijnych władz Izraela będących powiernikami żywej tradycji i interpretujących autorytatywnie w świetle historycznego rozwoju Objawienia sens ksiąg natchnionych. Pogłębiona $w$ ten sposób lub uzupełniona treść istniejącego już tekstu byłaby oczywiście dziełem Ducha Swiętego, t. j. natchniona na równi z pierwotną jego treścią. Dla poparcia swej teorii prelegent przytoczył kilka przykładów zapożyczonych z Psalmów 47, 22, 78 i 110 oraz z proroka Zachariasza $3,9$.

Drugim prelegentem tego przedpołudnia był Ks. R. S c h n a ckenburg, profesor Uniwersytetu $w$ Würzburgu i redaktor naukowego czasopisma biblijnego "Biblische $\mathrm{Z}$ eitschrift". W sposób jasny i przekonywający Ks. Sch a ckenburg wykazał, że czwarta ewangelia czyni wyraźne aluzje do sakramentów Chrztu, Eucharystii i Pokuty. 
Po południu zabrało głos 22 prelegentów. W sekcji I, t. j. „W stępu O gólneg o“, O. J. Schildenberger OSB z benedyktyńskiego opactwa Beuronu (Niemcy) rozpatrzył problem równoległych tekstów Starego Testamentu sprzecznych między sobą co do niektórych szczegółów oraz zagadnienie opowiadań etiologicznych, t. zn. objaśniających pochodzenie jakiejś nazwy, przedmiotu lub istniejącego stanu rzeczy. Zdaniem prelegenta kluczem do interpretacji tych odmiennych tradycji czy opowiadan etiologicznych jest cel, który przyświecał autorowi natchnionemu. Drugim prelegentem był O. A. K errig an OFII z Rzymu, który starał się uwypuklić ,sens pełny“ Joela $3,1-5$ w świetle tekstów Nowego Testamentu.

W sekcji „Bliskiego W s chodu“ O. J. Henniger SVD, profesor Uniwersytetu we Fryburgu Szwajcarskim, streścił wyniki osiemdziesięciu lat badań naukowych nad zagadnieniem totemizmu wśród ludów semickich. Następnie O. M. D a h o o d TJ, profesor Papieskiego Instytutu Biblijnego w Rzymie, przedstawił obecny stan badań nad językiem ugaryckim. Po czym O. J. J omie $\mathrm{r}$ OP z Kairu poruszył rzadko omawiany probiern współczesnej egzegezy Koranu w świecie arabskim oraz interpretacji $\mathrm{Bi}$ blii przez mułzumańskich egzegetów Koranu. Wreszcie P. J. Pirenne podała nową interpretację religii panującej w Hierapolis $\mathrm{w}$ Syrii na początku ery chrześcijańskiej.

W sekcji III - ,Srodowisko Nowego Testamentu" - Ks. P. Bläs er przeciwstawił hellenistyczne pojęcie „pneuma" w zestawieniu z "pneuma" w listach św. Pawła, u którego owe pojęcie wywodzi ze Starego Testamentu, jak na to wyraźnie wskazuja teksty qumrańskie. Następnie Ks. A. H o u s s i a u $z$ Louvain starał się wykazać, że wariant, ,egennethe u u Jana 1,13 pochodzi z okresu polemiki przeciwebionickiej. Ponieważ wariant ten odpierał sam przez się zarzuty Ebionitów zaprzeczających dziewiczemu pochodzeniu Chrystusa, przeto mógł on w okresie tej polemiki wziąc górę nad tradycyjnym wariantem „egennethesan“. W tejże sekcji Ks. J. R u y s c h a e r t, członek Papieskiej Akademii Archeologii wygłosił interesującą konferencję ilustrowana przeźroczami na temat ostatnich wykopalisk pod bazyliką św. Piotra w Rzymie.

W sekcji "Starego Testamentu" O. Chr. Brekelmans MSF przeprowadził krytykę teorii Prof. G. von $\mathrm{R}$ a d (,,Der Heilige Krieg im alten Israel") o ,heremie" w księdze Powtórzonego Prawa. Nastepnie Ks. H. R e n a r d, Prof. Katolickiego Uniwersytetu w Lille, przedłożył swój pogląd na temat mesjanizmu w pierwszej części księgi Izajasza. Po czym O. Prof. G. D u n c k e r OP z Rzymu przeprowadził egzegezę Iz 7, 15b. Czwartym prele- 
gentem był Ks. R. K o ch, który wyodrębnił poszczególne znacze-nia zwrotu ,ruah Jahwe" w księdze Izajasza. Ostatni zabrał głos: Ks. P. A uvray. Zdaniem prelegenta domniemane wpływy babilońskie na język Ezechiela nie wykluczają możliwości palestyńskiego okresu w misji proroka.

W sekcji „Nowego Testamentu Ks. P. Franquesa wytyczył granice wpływów środowiska na ewangelię św. Jana. Po czym O. Serafin de A u s e jo OFM Cap przeprowadził analizę pojęcia „ciała" zastosowanego do osoby Chrystusa w niektórych tekstach czwartej ewangelii. Nasteppnie O. M-E. B o is m a r d OP, profesor Jerozolimskiej Szkoły Biblijnej, wygłosił bardzo sugestywny referat o charakterze dodatkowym perykopy Jn 12, 4450. Wywody wybitnego profesora spotkały się $\mathrm{z}$ natychmiastowa reakcją części słuchaczy. Referat Ks. A. Feuillet, profesora Instytutu Katolickiego w Paryżu, na temat rozdz. 10 Apokalipsy św. Jana został odczytany przez jego kolegę, Ks. H. C a zelles.

W sekcji „Teologi i Biblijnej“ dwaj Jezuici, O. I. de la Potterie z Louvain i O. D. Mollat z Chantilly (Francja) uwypuklili znaczenia ,świadectwa“ i ,znaku“ w teologii św. Jana. Następnie Ks. A. Vögtle z Fryburga/Br. (Niemcy) podkreślił eklezjologiczne znaczenie nakazu misyjnego danego Apostołom przez Chrystusa zmartwychwstałego. Na koniec O. C. Spica OP, profesor Uniwersytetu we Fryburgu Szwajcarskim, określił znaczenie ,agape“ w Nowym Testamencie. O. Spic q przygotowuje obecnie na ten temat kilkutomowa prace naukową.

W środę plenarnej sesji Kongresu prezydował ponownie Ks. J. Coppens, który przedstawiając zgromadzonym pierwszego prelegenta dnia, O. A-M. Dubarle OP, profesora wydziałów dominikańskich w Le Saulchoir (Francja), podkreślił wielkie zasługi Dominikanów francuskich na polu biblijnym w służbie Kościoła. Po czym O. Dubarle określił i uwydatnił starotestamentalny pogląd na nature człowieka opierając się w swych wywodach głównie na księdze Genesis i wykazując, że zasadniczym elementem biblijnej koncepcji człowieka jest jego powołanie religijne.

Wygłoszenie drugiego referatu na sesji plenamej zostało powierzone Ks. E. D rioto n, profesorowi w "Collège de France". Odczyt słynnego egiptologa, będący owocem długoletnich i cierpliwych badań naukowych, wywołał dużą sensację. Wbrew bowiem powszechnemu mniemaniu egiptologów i egzegetów, prelegent wykazał w sposób przekonywający, że utwór egipski znany pod nazwą „Madrość Amenemope" nie jest źródłem księgi Przyp. 22,17-23,35, ale że jest on jedynie niezręcznym przekładem oryginału hebrajskiego będącego dziełem jakiegoś Izraelity prze- 
bywającego w Egipcie. Ten oryginał hebrajski a nie ,Mądrość Amenemope" stanowi źródło tego odcinka księgi Przypowieści.

Po południu w sekcji „Wstępu ogólnego“ Ks. Ed. Mi a s a u x $\mathrm{z}$ Louvain zestawił bilans opinii ostatnio wyrażonych na temat papirusu Bodmer II zawierającego większą część ewangelii św. Jana. Następnie O. J. P. S mith TJ, profesor Papieskiego Instytutu Biblijnego w Rzymie, przedstawił problemy i projekty związane $\mathrm{z}$ nowym wydaniem greckiego tekstu Nowego Testamentu, które zostało mu powierzone przez Instytut Biblijny. Po czym Prof. G. Garitte z Louvain wygłosił odczyt na temat gruzińskich przekładów Nowego Testamentu, a Ks. Prof. A. Gil Ule ci a z Madrytu podał do wiadomości szereg nieznanych dotychczas wariantów biblijnych Wulgaty z lekcjonarza gotyckiego "znajdującego się w katedrze w Saragossie.

W sekcji III - „S rodow is ko Nowego Testamentu“ O. J. Caubet It urbe SSCC przeprowadził porównanie między tekstami Nowego Testamentu a tekstami qumrańskimi odnoszącymi się do Jerozolimy i jej świątyni. P. Prof. J. J a n s sens wygłosiła referat na temat alegorycznej interpretacji epizodu Samarytanki (Jn 4) przez Heraklejona, jednego z czołowych przedstawicieli gnozy walentyńskiej (w. II), a Ks. Prof. J. M. M e ji a $\mathrm{z}$ Buenos Aires (Argentyna) porównał równoległe teksty kanonicznych ksiag Machabejskich i manuskryptów qumrańskich.

W sekcji ,Starego Testamentu" wygłoszono tego wieczoru aż 7 referatów. Najpierw Ks. H. C a z ell les z Paryża wygiosił godny uwagi odczyt na temat "Narodzenia Madrości" w księdze Przyp., r. 8. Następnym prelegentem był Ks. E.J. K i ss ane z Maynooth (Irlandia), który na podstawie qumrańskiego manuskryptu Izajasza (QIa) proponował nowe tłumaczenie Iz 9,8 Po czym Ks. Prof. H. H a a g z Lucerny podal w zarysie historie miejscowości Beer-Seba, starając się również wyjaśnić pochodzenie tej nazwy. O.J. Hofbauer TJ, profesor Uniwersyttetu w Innsbrucku, przeprowadził egzegezę Ps $88-89$, a Ks. Prof. A. Deissler z Fryburga/Br. (Niemcy) wykazała antologiczny charakter Ps 48 (47). Szóstym prelegentem był Ks. J. Coppens z Louvain, który przedłożył w zarysie próbę rozwiązania słynnego zagadnienia sensu indywidualnego czy też kolektywnego wyrażenia „ebed Jahwe“. Wreszcie Ks. H. J u n k e r, rektor wydziału teologii w Trewirze, wygłosił odczyt na temat „Błogosławieństwa“ i „Przekleństwa" w Starym Testamencie.

W sekcji „Nowego Testamentu“ Ks. J-E. Ménard z Montrealu (Kanada) objaśnił znaczenie określenia „Pais Theou“ w księdze Dziejów Apostolskich, gdzie zwrot ten stanowi tytuł mesjański. Następnie Ks. Prof. J. D u pl a c y z Lyonu starał się 
odpowiedzieć na pytanie: skąd wywodzi się zasadnicza rola wiary w religii chrześcijańskej. Po czym O. Prof. B. Riga ux OFM $z$ Brukseli wykazał, iż w świetle I listu do Tesaloniczan można odnaleźć zwroty i określenia treści chrześcijańskiej używane w Kościele jeszcze przed napisaniem I Tes. Wreszcie Ks. Prof. J. M. Gonzales $\mathrm{Ruiz}$ z Malagi (Hiszpania) uwydatnił eklezjologiczny sens nadany przez św. Pawła kilku abstrakcyjnym rzeczownikom greckim jak agape, pistis, pleroma, teleiotes, kleros i klesis.

W sekcji ,Teologii Biblijnej" Ks. Prof. A. Charbel z Sâo Paolo (Brazylia) starał siẹ wykazać, iż w krwawej ofierze zwanej ,.̌elamîm" krew nie ma znaczenia ekspiacyjnego. Drugi zaś prelegent, O. Prof. O. Carcia de la Fuente OESA z El Escorial (Hiszpania), uczynił kilka cennych uwag na temat żalu w Starym Testamencie. Nastepnie O. St. Ly on net TJ, profesor Papieskiego Instytutu Biblijnego w Rzymie, wyjaśnił pojęcie sprawiedliwości Bożej w liście do Rzymian 3, 5. Zdaniem prelegenta jest tu mowa o zbawczej sprawiedliwości Bożej. Interpretacji tej nie sprzeciwia się cytat z Psalmu ,Miserere“ (Rzym 3, 4), poniewaź należy tu wziąć pod uwage sens Psalmu w interpretacji danej mu przez św. Pawła. Po referacie O. P. B en ồt OP podzielił się z zebranymi wynikami swoich własnych dociekań na ten temat. Następnie Ks. Prof. K. H. Schelkle z Tübingen przedstawił eschatologiczną egzegezę Rzym 13,11-13 u Ojców Kościoła i w liturgii. Na koniec Ks. V. Ha m p zonachium poruszył problem monoteizmu w Starym Testamencie.

Czwartek był dniem wolnym od posiedzeń. Uczestnicy Kongresu mogli wziąc udział w zorganizowanej wycieczce do Gandawy i Brugii.

W piątek na plenarnym posiedzeniu Kongresu Ks. A. Desc a m p s, profesor Uniwersytetu w Louvain, wygłosił odczyt godny uwagi na temat metody $w$ teologii biblijnej. Zdaniem prelegenta pierwszy etap na drodze opracowania teologii biblijnej stanowi egzegeza filologiczno-historyczna tekstów biblijnych. Egzegeza ta jest $\mathrm{w}$ swej wewnętrznej strukturze całkiem niezależna od przesłanek filozoficznych czy teologicznych i w niczym nie różni się od interpretacji filologiczno-historycznej innych dzieł starożytności. Jest więc rzeczą niezbędną, by egzegeta starał się urobić w sobie duszę człowieka starożytności, czyli oderwał się w miarę możliwości od świata myśli, w którym żyjemy dziś w XX wieku. Stąd nie wolno mu zaniedbać żadnych środków, które poprzez powikłania czasów, miejsc, autorów, rodzajów literackich prowadzą do ujęcia tekstu natchnionego w jego rodzimym gruncie i środowisku historycznym. - Drugim etapem będzie ujęcie wyników badań filologiczno-historycznych w świetle wiary, ,sub lumine 
fidei", celem uchwycenia całości i pełni tajemnicy objawionej nam przez Boga w historycznym rozwoju dzieła Odkupienia. - Trzeci i ostatni etap będzie polegał na opracowaniu syntezy spekulatywnej w ramach jakiegoś systemu filozoficznego celem wyodrębnienia stałych wartości religijnych Biblii od elementów biblijnych związanych z okolicznościami czasu, kultury i cywilizacji.

Po Ks. Prof. Descamps zabrał głos O.G. Bernini TJ, profesor Papieskiego Uniwersytetu Gregoriańskiego w Rzymie. Przeprowadził on porównanie między nauką gminy qumrańskiej dotyczącą mesjańskiego charakteru sekty i wyrażoną w alegorii „sadu wiecznego" i jego „ogrodnika" (1QH VIII) a nauką Chrystusa Pana zawartą $\mathrm{w}$ przypowieściach, zwłaszcza w przypowieści o „nasieniu gorczycznym“. Alegoria hymnu qumrańskiego przedstawia tajemnice skromnej roli sekty aż do nadejścia ery mesjańskiej i na pierwszy rzut oka ma wiele podobieństwa z przypowieścią o "na si eniu gorczycznym“. Zasadniczo jednak opiera się na innej koncepcji tajemnicy królestwa Bożego, jak dobitnie wykazał to prelegent.

Po południu uczestnicy Kongresu zostali przyjęci przez władze akademickie Katolickiego Uniwersytetu w Louvain, przy czym J. E. Ks. Biskup H. van W a e y en bergh, rektor Uniwersytetu, wygłosił krótką przemowę.

Następnego dnia, tj. w sobotę, odbyło się w Wielkim Audytorium pawilonu "Civitas Dei" w Brukseli ostatnie posiedzenie Kongresu Biblijnego. Prezydował sesji J.E. Ks. Arcybiskup E. Forni, nuncjusz papieski. Po odczytaniu telegramu Ojca Swiętego, którego treść wyżej przytoczyliśmy, O.F.-M. B r a un OP, kapelan belgijskiego dworu królewskiego i profesor honorowy Uniwersytetu we Fryburgu Szwajcarskim, wygłosił odczyt na temat roli czwartej ewangelii w życiu Kościoła II wieku. Następnie O. E. Vogt TJ, rektor Papieskiego Instytutu Biblijnego w Rzymie; uzasadnił na podstawie kilku przykładów wziętych z księgi Ezechiela niezbędność naukowej krytyki literackiej, dzięki której jedynie można wykryć glosy i poprawki wprowadzone do istniejącego już tekstu Biblii przez późniejszych pisarzy natchnionych. $Z$ rzadką przenikliwością prelegent uwydatnił prawa, granice i cel krytyki literackiej w egzegezie biblijnej. Na koniec zabrał głos J. E. Ks. Arcybiskup B. Alf rink, którego przemowę już wyżej streściliśmy.

Przed rozstaniem się uczestnicy tego pierwszego Międzynarodowego Katolickiego Kongresu Nauk Biblijnych wyrazili życzenie, by w regularnych odstępach czasu - na przykład co pięć lat odbywały się tego rodzaju spotkania, w których katoliccy profesorowie biblistyki mieliby możność nawiązać między sobą bliższy kontakt, wymienić swe myśli i skonfrontować swe poglądy. 
Utworzenie międzynarodowego biura, które zajęłoby się organizowaniem podobnych kongresów, powierzono Komitetowi Organizacyjnemu $\mathrm{z}$ Louvain. W ten sposób inicjatywa powzięta przez grupę profesorów Katolickiego Uniwersytetu w Louvain doprowadziła do powołania stałego organizmu, którego zadaniem będzie zwoływanie i organizowanie tak owocnych dla biblistyki i Kościoła spotkań.

Ks. E. LIPINTSK! 